\title{
Does VEGF concentration in pre-eclamptic serum induce sVCAM-1 production in endothelial cell culture?
}

\author{
Sri B Subakir ${ }^{*}$, Nurul Paramita ${ }^{*}$ Ika Wardhani ${ }^{\dagger}$, Metta S Wiria ${ }^{f}$, Oentoeng Soeradi ${ }^{\S}$
}

\begin{abstract}
Abstrak
Pada preeklampsia terjadi peningkatan kadar VEGF (vascular endothelial growth factor). Selain mempunyai aktivitas mitotik dan meningkatkan permeabilitas membran sel endotel, VEGF dilaporkan dapat menginduksi produksi molekul sel adhesi oleh sel endotel. Molekul sel adhesi mempunyai fungsi merangsang perlekatan sel makrofag ke dinding pembuluh darah dalam proses inflamasi. Tujuan penelitian ini ialah untuk mengetahui pengaruh VEGF dalam serum preeklampsia pada produksi sVCAM-1 (soluble vascular cell adhesion molecule) oleh sel endotel dalam kultur. Duabelas sampel serum preeklampsia dan 11 serum kehamilan normal (kontrol) dengan konsentrasi 20\% dipajankan pada kultur sel endotel normal (HUVEC) selama 24 jam Semua subjek setuju berpartisipasi dalam penelitian ini dan menanda-tangani informed consent. Pengukuran kadar sVCAM-1 pada supernatan dilakukan dengan ELISA. Hasil menunjukkan kadar VEGF dalam serum preeklampsia cenderung lebih tinggi dari serum ibu dengan kehamilan normal. Kadar produksi VCAM-1 oleh sel endotel yang dipajankan pada serum preeklampsia lebih tinggi secara bermakna dari yang dipajankan oleh serum kontrol $(p<0,05)$. Tidak ada korelasi antara kadar VEGF dalam serum preeklampsia dan kontrol terhadap produksi sVCAM-1 oleh kultur sel endotel. (Med J Indones 2005; 14: 3-6)
\end{abstract}

\begin{abstract}
Serum concentrations of VEGF (Vascular Endothelial Growth Factor) are elevated in preeclampsia. In addition to inducing mitosis and increase permeability of endothelial cells, VEGF was reported to activate endothelial cells to produce cell adhesion molecules. Cell adhesion molecules play an important role in the inflammation process by inducing adherence of leukocytes in blood stream to the endothelial cells. The aim of this study is to investigate the effect of VEGF in serum from preeclamptic patients on sVCAM-1 (soluble vascular adhesion molecules-1) production in endothelial cell culture. Twelve sera from women with preeclampsia and 11 from women with normal pregnancy (controls) in $20 \%$ concentration were added to human umbilical vein endothelial cell culture (HUVEC) and incubated for 24 hours. All subjects have agreed to participate in this study and signed the informed consent form. sVCAM-1 concentration in the supernatant was measured by ELISA. VEGF concentration tends to be higher in preeclamptic serum than control, but the difference is not stastitically significant. The production of sVCAM-1 by endothelial cells exposed to preeclamptic serum was significantly higher than the production by endothelial cells exposed to serum from control ( $p<0.05)$. No correlation was found between the difference in VEGF concentrations in preeclamptic and control sera, and sVCAM-1 production by endothelial cell culture. (Med J Indones 2005; 14: 3-6)
\end{abstract}

Keywords: endothelial cell, preeclampsia, VCAM, VEGF

Preeclampsia is a pregnancy-specific disorder characterized by hypertension, proteinuria and edema. Although the etiology of preeclampsia is still unclear, it is believed

\footnotetext{
* Department of Physiology, Faculty of Medicine, University of Indonesia, Jakarta, Indonesia

'Department of Community Medicine, Faculty of Medicine, University of Indonesia, Jakarta, Indonesia

${ }^{f}$ Department of Pharmacology, Faculty of Medicine, University of Indonesia, Jakarta, Indonesia

${ }^{\S}$ Department of Biology, Faculty of Medicine, University of Indonesia, Jakarta, Indonesia
}

that the clinical symptoms are the result of alteration in endothelial cell functions. Evidence of endothelial dysfunction includes increased sensitivity of endothelial cells to vasoconstrictor agent, increased capillary permeability, and elevation of soluble adhesion molecules levels. ${ }^{1,2,3}$

In recent years, a number of molecules, which mediate leukocyte-endothelial adhesion have been identified, these include E-selectin, and vascular cell adhesion molecule-1 (VCAM-1). The expression of VCAM-1 is induced by cytokine or bacterial endotoxin. 
It is believed that oxidative stress also lead to increase expression of VCAM-1 on endothelial cells in preeclampsia. ${ }^{3}$ Several adhesion molecules also exist in soluble isoforms. Cell activation involves a more rapid shedding of adhesion molecules from the cell surface. Elevated serum levels of soluble adhesion molecules might be a useful way to monitor the disease activity. Recent studies have demonstrated that serum levels of VCAMs is increased in preeclampsia. ${ }^{4}$

Vascular endothelial growth factor (VEGF) is a specific mitogen and survival factor for endothelial cells, and locally initiates permeabilization of blood vessels, extravasation of plasma protein and facilitates angiogenesis. ${ }^{5,6}$ It is believed that placental hypoxia leads to elevation of VEGF and mediates endothelial cell activation in preeclampsia. ${ }^{6,7}$ Serum VEGF is elevated in preeclampsia and is correlated with the severity of the disease. It is assumed that the elevation of VEGF is due to placental hypoxia and mediates endothelial function of preeclampsia. ${ }^{7,8}$ VEGF also promotes the inflammatory process by causing vascular leakage and mobilizing leucocyte. ${ }^{6}$ It is not clear whether VEGF will induce sVCAM-1 production by endothelial cell in preeclampsia.

The purpose of this study was to investigate the correlation between VEGF levels in serum preeclampsia and sVCAM-1 production by endothelial cells in culture (HUVEC) when exposed to serum of women with preeclampsia.

\section{METHODS}

\section{Subjects}

Twelve women with preeclampsia and 11 women with normal pregnancy as control between the ages of 20-35 years were recruited from the Budi Kemuliaan Maternity Hospital in Jakarta. Preeclampsia was defined by the following criteria: hypertension (>140/90 mmHg, or an increase of $30 \mathrm{mmHg}$ systolic or $15 \mathrm{mmHg}$ diastolic blood pressure compared with value obtained before 20 weeks gestation), proteinuria or edema of at least +2 . The control group consists of healthy pregnant women, and matched with the preeclampsia group for age, gestational age and parity. All of subjects were recruited to the study on the basis of fully informed consent. Blood samples were collected and allowed to coagulate and then centrifuged at $1500 \mathrm{~g}$ for 15 minutes. The serum was stored at $-20^{\circ} \mathrm{C}$ until used.

\section{Endothelial cell culture}

Endothelial cells from human umbilical vein were isolated and cultured using the method described by Jaffe. ${ }^{9}$ The neonates were at term, of normal birth, with no intrapartum infection, and having clear amniotic fluid. Harvested cells were divided into two equal parts and each seeded into 4 wells of multidish culture (Nunc Corporation, Denmark) in M199 containing $20 \%$ fetal calf serum (FCS, Gibco Laboratories, USA), antibiotic and anti fungal preparation. After reaching $80 \%$ confluence, the cells were washed with phosphate buffer saline (PBS) and then 3 wells were given either $1 \mathrm{ml} \mathrm{M} 199$ phenol red free containing $20 \%$ preeclamptic serum or $20 \%$ control serum. Well number 4 was reserved for the control (blank). The cells were then incubated at $37^{\circ} \mathrm{C}$ and $5 \% \mathrm{CO}_{2}$ for 24 hours. The supernatant was collected and stored at $-80^{\circ} \mathrm{C}$, while the cells were harvested and counted by a hemocytometer.

\section{VEGF measurement}

Preeclamptic and control serum were diluted with M199 media to reach 20\% concentration, and used to induced sVCAM production by endothelial cells. CytElisa Human VEGF kit (ams Biotechnology, UK) was used for measuring VEGF concentration. Mouse monoclonal antibodies generated against human VEGF were used to capture human VEGF in sample. Simultaneously, biotinylated rabbit anti-human VEGF polyclonal antibodies were used to detect VEGF in the sample. The assay was visualized using a streptavidin alkaline phosphatase conjugate and an ensuing chromagenic substrate reaction (deep red), which absorb light at $490 \mathrm{~nm}$. The sensitivity of this assay was $18.6 \mathrm{pg} / \mathrm{ml}$, inter-assay variation was $11.1 \%$, and intra-assay variation was $8.9 \%$.

\section{VCAM assay}

The concentration of sVCAM-1 in the supernatant of the endothelial cell culture was measured by a sandwich enzyme linked immunoassay. A monoclonal antibody specific for VCAM-1 was coated onto the wells of the microtitre. The samples were pipetted onto the wells, and then biotinylated monoclonal antibody specific for VCAM-1 was added and 
incubated for 1 hour at room temperature. After washing, streptavidin-peroxidase was added. It was the incubated again for 30 minutes at room temperature and finally chromogen TMB added and color was allowed to develop for 10-15 minutes. After adding $\mathrm{H}_{2} \mathrm{SO}_{4}$ and it was read with absorbance at 450 $\mathrm{nm}$. The sensitivity of the assay was $0.9 \mathrm{ng} / \mathrm{ml}$, interassay was $5.2 \%$ and intra-assay was $3.1 \%$.

\section{Statistical analysis}

Mean 20\%VEGF serum level and sVCAM-1 production by endothelial cells culture were calculated. Differences in serum VEGF and s-VCAM concentrations of the supernatant between the groups were analyzed using Student's $t$ test at $\mathrm{p}<0.05$. The correlation between $20 \%$ VEGF serum levels and sVCAM-1 production by endothelial cells was determined with Pearson test.

\section{RESULTS}

The concentration of VEGF in serum of preeclamptic patients tended to be higher than in normal pregnancy $(33.19 \pm 0.87 \mathrm{pg} / \mathrm{ml}$ versus $32.62 \pm 0.63 \mathrm{pg} / \mathrm{ml})$, but the difference was not significant. sVCAM production by endothelial cells exposed to preeclamptic sera was significantly higher than cells exposed to serum from normal pregnancy $(1.326 \pm 0.745 \mathrm{ng} / \mathrm{ml}$ versus 0.755 $\pm 0.415 \mathrm{ng} / \mathrm{ml}), \mathrm{p}<0.05$ and $\mathrm{t}=2.30$ ). No correlation was found between concentration of VEGF in the serum and sVCAM-1 production in the endothelial cell in culture.
Although the levels of VEGF in serum preeclamptic women was higher than in serum from normal pregnancy, and sVCAM-1 production by EC exposed to the preeclamptic sera was also higher than in normal pregnancy, no correlation was found between concentration of VEGF in the serum and concentration of sVCAM-1 produced.

\section{DISCUSSION}

Hypoxia is involved in the synthesis of both VEGF and VCAM. Hypoxia also increased leucocyte adhesion to endothelium. In preeclampsia is believed that oxidative stress occurs and lead to hypoxia. Elevated serum levels of soluble adhesion molecules may be useful monitors of disease activity. In this study have demonstrated that concentration of VCAMs production is increased in preeclampsia, but we failure to got correlation of VEGF and SVCAM-1 production. The other study reported that VEGF stimulated expression VCAM-1 in endothelial cell ${ }^{10}$ Maybe the VEGF concentration in preeclamptic serum is not to high and many factors in the preeclamptic sera involved production of molecule adhesion.

\section{Acknowledgment}

This study funded by Hibah Tim Pasca 2003. DRPM Direktorat Jenderal Pendidikan Perguruan Tinggi Republik Indonesia. We thank Ms Neneng for measuring VEGF and VCAM

Table 1. Mean and SD of VEGF concentration, number of EC and concentration of sVCAM-1 production by EC culture

\begin{tabular}{|c|c|c|c|}
\hline & Preeclampsia & Normal pregnancy & $\mathrm{S} / \mathrm{NS}$ \\
\hline $\begin{array}{l}\text { Concentration of VEGF } \\
\text { in } 20 \% \text { sera }\end{array}$ & $33.19 \pm 0,87 \mathrm{pg} / \mathrm{ml}$ & $32.62 \pm 0.63 \mathrm{pg} / \mathrm{ml}$ & NS \\
\hline The number of EC & $\begin{array}{c}9.75 \pm 4,75 \\
\left(10^{4}\right) \text { cells }\end{array}$ & $\begin{array}{l}12.73 \pm 6.65 \\
\left(10^{4}\right) \text { cells }\end{array}$ & NS \\
\hline $\begin{array}{l}\text { Concentration of sVCAM-1 } \\
\text { in culture }\end{array}$ & $1.326 \pm 0.745 \mathrm{ng} / \mathrm{ml}$ & $0.755 \pm 0.415 \mathrm{ng} / \mathrm{ml}$ & S \\
\hline
\end{tabular}




\section{REFERENCES}

1. Brockelsby JC, Anthony FW, Johnson IR, Philip N. The effect of vascular endothelial growth factor on endothelial cells: A potential role in preeclampsia. Am J Obstet Gynecol 2000; 182: 176-83.

2. van Beek E, Peeters LLH. Pathogenesis of preeclampsia: A comprehensive model. CME Review Article 1998; 53: 233-9.

3. Endressen MJR, Morris JM, Nobrega AC, et al. Serum from preeclamptic women induces vascular cell adhesion molecule-1 expression on human endothelial cells in vitro: A possible role of increased circulating levels on free fatty acids. Am J Obstet Gynecol 1998; 179: 665-70.

4. Austgulen R, Lien E, Vince G, Redman CWG. Increased maternal plasma levels of soluble adhesion molecules (ICAM-1, VCAM-1, E-selectin) in preeclampsia. Eur J Obstet Gynecol Reprod Biol 1997; 71: 53-8.

5. Reynolds LP, Redmer DA. Angiogenesis in the placenta. Biol Reprod 2001; 64: 1033-40.
6. Jelkman W. Pitfalls in the measurement of circulating Vascular Endothelial Growth Factor. Clin Chem 2001; 47: 617-23.

7. Baker PN, Krasnow J, Roberts JM, Yeo KT. Elevated serum levels of Vascular Endothelial Growth Factor in patient with preeclampsia. Obstet Gynecol 1995; 56: 515-21.

8. Ong S. Angiogenesis and placental growth in normal and compromised pregnancies. Balliers Clin Obstet Gynecol 2000; 14: 969-80.

9. Jaffe, E.A. (1984) Culture and identification of large vessel endothelial cells. In Jaffe, E.A. (ed.) Biology of endothelial cells, Martinus Nijhoff Publishers, Boston, pp.1-13.

10. Kim I, Moon SO, Kim SH, et al. Vascular endothelial growth factor expression of intracellular molecule I (ICAM-1), vascular cell adhesion molecule-1 (VCAM-1) and E-selectin through nuclear-kappa $\mathrm{B}$ activation in endothelial cell. J Blood Chem 2001; 276(10): 7614-20. 